(2014) 22 IIUMLJ 1

\title{
RECIPE FOR DISASTER? THE DEPLOYMENT OF PATENTS OVER ENVIRONMENTALLY SOUND TECHNOLOGIES (ESTs)
}

\author{
Ida Madieha Abdul Ghani Azmi *, Suzi Fadhilah \\ Ismail $^{* *} \&$ Jeong Chun-Phuoc
}

\begin{abstract}
The development, deployment and dissemination of lowcarbon and other environmentally sound technologies (ESTs) is critical in our response to climate change. Yet, many of these critical technologies are patented and belong to private entities. Malaysia through the National Renewable Energy Policy and National Green Technology Policy, aims to leverage on green technology as a double edge sword; as a tool to spur economic activities whilst at the same time ensuring sustainable development and conservation of the environment for future generations. In order to enhance the uptake of ESTs, Malaysia has identified renewable energy as an impetus. This paper explores the discourse between the patents and climate change at the international level. As the diffusion of ESTs requires modification and adaptation,
\end{abstract}

\footnotetext{
* Prof. Ida Madieha Abdul Ghani Azmi, Professor, Ahmad Ibrahim Kulliyyah of Laws, International Islamic University Malaysia, Malaysia, E-mail: imadieha@iium.edu.my,

** Assistant Prof. Dr. Suzi Fadhilah Ismail, Assistant Professor, Ahmad Ibrahim Kulliyyah of Laws, International Islamic University Malaysia, Malaysia, E-mail: suzi@iium.edu.my,

*** Jeong Chun-Phuoc, Senior Lecturer, Faculty of Law, Multi Media University, Malaysia, E-mail: jeongchunphuoc@gmail.com.
} 
the issue of how much this can take place without the consent of the patent owner is discussed. The scope of scientific research exemption in Malaysia is examined with a view of determining whether it can support research activities with commercial activities and the act of inventing around a patent. It is proposed that for effective transfer of ESTs to take place, the scientific research provision be expanded to cover all forms of research necessary for the diffusion of technology, regardless of its commercial and transformative ends.

Keywords: Patent, scientific research, ESTs and Green Technologies, Green Policy and Strategy, treaty obligations.

\title{
RESIPI UNTUK BENCANA? PENGGUNAAN PATEN KE ATAS TEKNOLOGI-TEKNOLOGI MESRA ALAM (ESTs)
}

\begin{abstract}
ABSTRAK
Pembangunan, penggunaan dan penyebaran rendahkarbon dan lain-lain teknologi mesra alam (ESTs) adalah penting sebagai tindak balas kita terhadap perubahan iklim yang berlaku. Namun begitu, kebanyakan teknologi kritikal ini dipatenkan dan dimiliki oleh entiti-entiti persendirian. Malaysia melalui Dasar Tenaga Boleh Diperbaharui Negara dan Dasar Teknologi Hijau Negara, berhasrat untuk meningkatkan penggunaan teknologi hijau melalui pendekatan serampang dua mata; sebagai alat untuk menggalakkan aktiviti ekonomi dan pada masa yang sama memastikan pembangunan mapan dan pemuliharaan alam sekitar untuk generasi akan datang. Bagi membolehkan peningkatan penggunaan ESTs, Malaysia telah mengenalpasti tenaga yang boleh diperbaharui sebagai pencetus. Kertas kerja ini meneroka perbincangan di antara perubahan iklim dan hak paten di peringkat antarabangsa. Oleh kerana penyebaran ESTs memerlukan pengubahsuaian dan penyesuaian, isu tentang sejauh mana ia dapat dilaksanakan tanpa mendapat keizinan pemilik paten juga
\end{abstract}


dibincangkan. Skop pengecualian penyelidikan saintifik di Malaysia dikaji dengan tujuan untuk menentukan samada ia dapat menyokong aktiviti penyelidikan dengan aktivitiaktiviti komersil dan rekacipta berkaitan sesuatu paten. Bagi pemindahan teknologi ESTs secara berkesan, adalah dicadangkan bahawa peruntukan penyelidikan saintifik diperluaskan meliputi semua bentuk penyelidikan yang perlu bagi penyebaran teknologi, tanpa mengira samada hasil kajian tersebut memberikan kesan komersil mahupun transformatif.

Kata kunci: Paten, kajian saintifik, Teknologi Hijau dan Mesra Alam EST, strategi dan dasar hijau, obligasi dalam perjanjian.

\section{INTRODUCTION}

Climate change which causes disproportionate changes in temperature, weather patterns, sea levels and sea temperatures has put a lot of countries and people at extreme risk. The catastrophic tsunami events from 2004-2011, namely the tsunami that struck Sumatra, Indonesia (26 December 2004) and the tsunami in North Pacific Coast, Japan (11 March 2011), and the recent super typhoon Haiyan 2013 that made landfall in the Philippines have left thousands of dead and thousands more displaced. This indicates that more needs to be done to alleviate the impact of climate change. ${ }^{1}$ As the global communities scramble to find solutions to address climate change, there have been calls for greater availability of green technologies for nations to use.

Green technology is the development and application of products, equipment and systems used to conserve the natural environment and resources, which minimises and reduces the negative impact of human activities. ${ }^{2}$ Green technologies is further defined in Chapter 34 of Agenda

1 Max Fischer, 8 maps that explain why Typhoon Haiyan hit the Philippines so hard, the Washington Post, Nov. 15, 2013, available online at http://www.washingtonpost.com/blogs/worldviews/wp/2013/ 11/15/8-maps-that-explain-why-typhoon-haiyan-hit-the-philippines-sohard/ (viewed Nov. 17, 2013).

2 The definition of 'green technology' is available at: <http:// www.kettha.gov.my/en/content/definition-green-technology $>$ 
21 (The United Nations Programme of Action from Rio, 1992), as "Environmentally sound technologies (ESTs) protect the environment, are less polluting, use all resources in a more sustainable manner, recycle more of their wastes and products, and handle residual wastes in a more acceptable manner than the technologies for which they were substitute."3

As most of the green technologies are patented and privately owned (based on patent data statistics from the Trilateral Offices ${ }^{4}$ and major Patent Offices), numerous proposals have been submitted within the domain of the United National Framework Convention on Climate Change (UNFCCC) and Kyoto Protocol for revision of the patent system in order to create easier access to 'climate friendly technology.'

In 2010, a major breakthrough was achieved when global representatives from both developed and developing countries formally at the Conference of Parties ${ }^{5}$ (COP-16) finally agreed not to disagree to the establishment of the 'Technology Mechanism' (TM 2010) ${ }^{6}$ at the idyllic resort of Cancun, Mexico. ${ }^{7}$ The 'Technology Mechanism' (TM $2010)^{8}$ transformed the antiquated approach in green technology transfer

3 'WIPO GREEN: Facilitating Dissemination of Green Technology,' June 2012, by Anja von der Ropp, Legal Officer, Global Challenges Division, WIPO, at http://www.wipo.int/wipo_magazine/en/2012/03/ article_0006.html.

$4 \quad$ 'The Trilateral Co-operation was set up in 1983 between the European Patent Office (EPO), the Japan Patent Office (JPO) and the United States Patent and Trademark Office (USPTO),' see http:// www.trilateral.net/about.html.

5 The Conference of Parties is the supreme decision-making body of the United Nations Framework Convention on Climate Change. All States that are Parties to the Convention are represented at the COP, at which they review the implementation of the Convention. See United Nations Framework Convention on Climate Change online at https://unfccc.int/ bodies/body/6383.php.

6 The Technology Mechanism consists of a Technology Executive Committee (TEC) and a Climate Technology Centre and Network (CTCN), see http://unfccc.int/focus/technology/items/7000.php.

7 'Cancun Climate Change Conference - November 2010,' at http:// unfccc.int/meetings/cancun_nov_2010/meeting/6266.php.

8 The Technology Mechanism consists of a Technology Executive Committee (TEC) and a Climate Technology Centre and Network 
from a useless 'TNA-based and capacity-building' methodology to a more practical approach by integrating Public-Private Partnerships (PPPs); joint industrial R\&D innovations; and, the transfer of critical green technologies and the funding of such transfer by developed countries to developing countries. Datuk Seri Najib Tun Razak, as the PM of Malaysia (during the recent launch of the High Impact Biodiversity and Development Post 2015 Forum, KL, Malaysia 2013) did not mince his words when he reminded developed countries that Malaysia, and developing countries for that matter, were committed to adopt green technologies to address climate change, but this is subject to "technology transfer and the new additional funding from developed nations."

This article considers the relevance of the patent system to the development, deployment and dissemination of low carbon and other environmental technologies which are critical to our response to climate change. The paper starts with a brief foray into the National Renewable Energy Policy and the National Green Technology Policy and these are then briefly analysed to state the relevance of ESTs to Malaysian interests. It then moves to the initiatives under United National Framework Convention on Climate Change (UNFCCC) ${ }^{10}$ and Kyoto Protocol as well as the World Intellectual Property Organisation (WIPO) and World Trade Organisation (WTO) to link patent with technology transfer obligations. This is followed with an examination of the relevant provisions of the Patents Act 1983 that requires revision if technology transfer of green patents were to be supported to the fullest. The specific focus of the article is the experimental use provision in the Patents Act 1983. This is done by analysing the current discourse on the preferred scope of experimental use in Australia and the United Kingdom (UK) in order to support research and the growth of useful technologies. The paper ends with suggesting that more needs to be done to realign the patent system to make it useful in the development and deployment of green technologies.

(CTCN), see http://unfccc.int/focus/technology/items/7000.php. "PM: 40 percent cut in carbon emission," NST, 5 Nov. 2013, at page 2. UNFCCC is an international treaty negotiated under the aegis of Kyoto Protocol that seeks to stabilize greenhouse gas concentrations in the atmosphere at a level that will prevent dangerous human interference with the climate system. 


\section{GREEN TECHNOLOGY AND MALAYSIA'S NATIONAL POLICIES}

The interest that Malaysia has over ESTs or green technology goes beyond environmental conservation but extends as well to the deployment of these technologies to spur economic activities in the country. In 2009, the PM of Malaysia, Datuk Seri Najib Tun Razak, in the official launching of the National Green Technology Policy 2009 explained that "Green Technology is the development and application of products, equipment and systems used to conserve the natural environment and resources, which minimises and reduces the negative impact of human activities." However, interestingly, he took a different view at the recent official launch of the High Impact Biodiversity and Development Post 2015 Forum, Kuala Lumpur, Malaysia 2013 when he viewed the utility and purpose of green technology as a tool to achieve "A balance between conservation and development." $"$ This Malaysian approach is a rather practical approach, an act that operationalises the Brundtland Commission 1983 advocacy that emphasises national economic development to be one of "sustainable development (is the development) that meets the needs of the present without compromising the ability of future generations to meet their own needs."

One area which has been targeted to spearhead the green technology initiatives in Malaysia is Renewable Energy (RE). ${ }^{12}$ The National Renewable Energy Policy and Action Plan (2009), ${ }^{13}$ aims at enhancing the utilisation of indigenous renewable energy and energy resources to contribute towards the national electricity supply security and sustainable socio-economic development. The National Green Technology Policy 2009 followed suit to provide for 'direction and motivation for Malaysians to continuously enjoy good quality living and a

$11 \quad$ High Impact Biodiversity and Development Post 2015 Forum, KL, Malaysia 2013 at http://www.nst.com.my/nation/general/a-balancebetween-conservation-and-development-says-najib-1.391781.

12 National Green Technology Policy 2009 available at http:// www.kettha.gov.my.

13 National Renewable Energy Policy and Action Plan (2009), at http:// seda.gov.my/. 
healthy environment.' The green technology initiatives in Malaysia embrace three approaches: conservation, minimisation and reductions. For a technology to be qualified as 'green technology' it must profess the following criteria: it mimimises the degradation of the environment; it has zero or low green house gas (GHG) emission; it is safe for use and promotes healthy and improved environment for all forms of life; it conserves the use of energy and natural resources and it promotes the use of renewable energy. The Four-Fuel Diversification Policy $1981^{14}$ further encourages research and development on renewable energy, especially biomass, as a viable fuel resource in addition to oil, gas, coal and hydro. This old 1981 policy was replaced by a Five-Fuel Diversification Policy in 2000, adding renewable energy (RE) as a fifth fuel source for Malaysia. Through these Five-Fuel Diversification initiatives, Malaysia has made some headway particularly in renewable energy such as PV System and Solar Panel, and to a certain extent, biomass. That was the backwaters in 2009. However, in 2013, under the Malaysian Industry to Government High Technology (MIGHT), Malaysia's first biomass ${ }^{15}$ plant project, known as MyBIOMASS, ${ }^{16}$ was conceived and launched to raise biomass to the next level. Solar PV saw increased FDIs and the engagement of several global solar PV players namely First Solar, ${ }^{17}$ Sun Power, Q-Cells, ${ }^{18}$ AU Optronics, ${ }^{19}$ Panasonic Energy Malaysia Sdn. Bhd. and others.

14 See Speech entitled 'The Future Of Energy In Malaysia' Luncheon Talk By Yb Dato' Sri Peter Chin Fah Kui,Minister Of Energy, Green Technology And Water At The Malaysian International Chamber Of Commerce \& Industry (Micci) Tuesday, 24th April 2012, 12.30 pm, Hotel Renaissance Kuala Lumpur at http://www.kettha.gov.my/en/content/ future-energy-malaysia. Biomass refers to the process of recycling of organic waste into fuel. 'MYBiomass was created as one of the 'quick-wins' approved by the Honourable Prime Minister of Malaysia during the Inaugural Meeting of Global Science and Innovation Advisory Council (GSIAC) on 17 May 2011, in New York, United States,' at http://www.gsiac.org/ index.cfm?\&menuid=15\#sthash.wEurrhXz.dpuf.

17 First Solar at http://www.firstsolar.com/.

18 Q-Cells at http://www.q-cells.com/en/index.html. 
The Green Building Index (GBI) (2009) (in Singapore known as the 'Green Mark, ${ }^{20}$ and in the USA, referred to as 'LEED' ${ }^{21}$ certification) adopted by both the Malaysian Institute of Architects and the Association of Consulting Engineers Malaysia is another key milestone in the development of green technology in Malaysia. However, there is much to be desired (in terms of green technological audit and compliance standards, as observed from the GIB, Green Mark and LEED ${ }^{22}$ standards). In order to accelerate this process, more needs to be done in acquiring the right green technology and critical knowledge that could be used for the diffusion of these technologies. As the green technologies are mainly foreign owned, the growth of this industry in Malaysia is hampered significantly. The discussion now moves to the role of intellectual property in the development of ESTs.

\section{INTELLECTUAL PROPERTY AND CLIMATE CHANGE}

The deployment of environmentally sound technologies (ESTs) is essential to alleviate the harsh impact of climate change. ${ }^{23}$ For these patents to save the world, it is imperative that these technologies are transferred to the countries needing them. ${ }^{24}$ Unfortunately, these intellectual property

20 'The BCA Green Mark Scheme was launched in January 2005 as an initiative to drive Singapore's construction industry towards more environment-friendly buildings, 'see Introduction at http:// www.bca.gov.sg/greenmark/green_mark_buildings.html. and For CA Green Mark Assessment Criteria in Singapore, see http:// www.bca.gov.sg/greenmark/green_mark_criteria.html.

'LEED, or Leadership in Energy \& Environmental Design.... is a green building tool that addresses the entire building lifecycle recognizing best-in-class building strategies.' Opening introduction at http:// www.usgbc.org/leed.

22 For more about LEED, see http://www.usgbc.org/articles/about-leed And For LEED rating systems, see http://www.usgbc.org/leed/ratingsystems.

23 Rimmer, Mathew (2011), Intellectual Property and Climate Change: Inventing Clean Technologies, Edward Elgar Publishing.

24 Rimmer, Mathew (2011) A Proposal for a Clean Technology Directive: European Patent Law and Climate Change. Renewable Energy Law and Policy Review, 3, 194-204. 
rights (IPRs) are in the hands of a few which have the ability to create a monopolistic situation where dissemination of knowledge is restricted on account of limited access and higher prices for climate friendly technologies. ${ }^{25}$ It was considered in the UNFCCC that intellectual property rights act as a barrier to effective technology transfer to green technologies. ${ }^{26}$ To that end, Articles 4.1(c), 4.5, 4.3 and 4.7 of UNFCCC were categorical in the obligation to transfer these technologies to the countries needing them. ${ }^{27}$ These articles took credence from the preamble of the TRIPS Agreement, particularly Articles $7 \& 8$ of the Agreement. Article 7 provides the general objective of intellectual property as the promotion of technological innovation and the transfer of these technologies to the mutual advantage of their producers and users. Article 8 meanwhile guarantees the member countries freedom to formulate or amend their laws and legislations in order to adopt measures necessary to protect public health and nutrition. To assist the member countries in identifying relevant technologies, the WIPO has kick-started the WIPO Green Initiatives as a platform to match the available technologies, knowhow and expertise of "technology providers" with the expressed needs of "technology seekers." 28 To further facilitate searches for patent information relating to so-called ESTs to help identify existing and emerging green technologies and potential partners for further R\&D and commercial exploitation, WIPO has set up a specialised patent

$25 \quad$ Nanda, Nitya \& Srivastava, Nidhi, "Clean Technology Transfer and Intellectual Property Rights," Sustainable Development Law and Policy, 9, 42-48.

26 Hall, Bronwyn H \& Helmers C, "The Role of Patent Protection in (Clean/ Green) Technology Transfer," Santa Clara Computer and High Tech Law Journal, 26 (2009) 487-532; to which Lane disagreed. See Lane, Eric, "Clean Tech Reality Check: Nine Clean Tech Reality Check: Nine International Green Technology Transfer Deals Unhindered by Intellectual Property Rights," Santa Clara Computer and High Tech Law Journal, 26 (2010) 533-557.

27 Gechlik, Mei, "Making Transfer of Clean Technology Work: Lessons of the Clean Development Mechanism," San Diego International Law Journal, 11 (2009) at 227-286.

28 Anja von der Ropp, WIPO Green: Facilitating Dissemination of Green Technology, available at: http://www.wipo.int/wipo_magazine/en/2012/ 03/article_0006.html. 
classification known as the International Patent Classification Green Inventory. Countries like United Kingdom, Australia, Korea, Japan, United States, Canada, Brazil, China and Malaysia have also been fast tracking the patent examination of 'green technologies' in order to accelerate the deployment of these technologies. ${ }^{29}$

To bolster the process further, it is critical that the present patent system that feeds innovation be further reformed to "cure the market failure in environmental innovation. ${ }^{30}$ Absent that, there is no middle ground between the strong IPRs desired by the developed nation firms and the access concerns of the developing nations. ${ }^{31}$ Among the reforms suggested are compulsory licensing, modifying the patent term, streamlining the patent process, lowering patent standards and introducing a patent rewards system. ${ }^{32}$ For effective deployment of ESTs, it is imperative that these technologies be modified and adapted to suit local needs and conditions. For this to take place there must be a flexible experimental use exception which is the key focus of this paper.

Issue paper No. 37, International Centre for Trade and Sustainable Development (ITCSD), Geneva Switzerland.

Taylor, Scott., "Where are the Green Machines?: Using the Patent System to Encourage Green Invention and Technology Transfer," The Georgetown International Environmental Law Review, 23 (2011) 577607.

$31 \quad$ Taylor, Scott., "Where are the Green Machines?: Using the Patent System to Encourage Green Invention and Technology Transfer," The Georgetown International Environmental Law Review, 23 (2011) 577607 , at p. 601.

Mandel, Gregory N, "Promoting Environmental Innovation with Intellectual Property Innovation: A New Basis for Patent Rewards," Temple Journal Scientific Technology and Environmental Law, 24 (2005) 51-70. See also Nunnenkamp, Kenneth J, “Compulsory Licensing of Critical Patents under Comprehensive Environmental Response, Compensation and Liability Act 1980 (CERCLA)?" Natural Resources and Environmental Law, 9, 397-420. 


\section{PATENT EXCEPTIONS, EXPERIMENTAL USE AND ADAPTATION OF TECHNOLOGIES}

One possible obstacle to the absorption of technologies is the restriction on the modification and adaptation of patented technologies without the consent of the patent owner. In 2006, the Gower Review of Intellectual Property ${ }^{33}$ stressed on the need to maintain a balance in the patent system by revising the research exceptions. The Report found that the research exceptions grant researchers the freedom to conduct research on patented inventions for the purposes of understanding and improving existing products and processes without the need to get permission. This exception reduces the transaction costs involved in clearing rights for use of patents in experimentation and research. The number of patented materials required to conduct experiments is often so great that the transaction costs of obtaining licenses for all of them are 'prohibitive.'

The justifications for experimental use were underlined in the Report by the Australian Law Reform Committee (2004) $)^{34}$ to be as follows:

a. enables the validity of existing patents to be properly tested by experimentation;

b. enables experiments to be conducted to determine whether a patentable invention falls within the scope of an existing patent;

c. promotes the attainment of new knowledge about patented inventions;

d. promotes the development of new and improved inventions and reduces the likelihood of monopolisation of a new area of technology by a patent holder;

$33 \quad$ Available at www.hm-treasury.gov.uk.

$34 \quad$ 'Genes and Ingenuity: Gene Patenting and Human Health,'Australian Law Reform Commission, (ALRC 99, 2004) available at www.alrc.gov.au/ publications/report-99. 
e. removes a burden from researchers, who might otherwise need to conduct extensive patent searches and obtain advice from lawyers and patent attorneys; and

f. involves minimal interference with the patent holder's economic interests in exploiting its patent.

The WTO jurisprudence in the Canada-Patent Protection 2000 provides a clear light in the fundamental value of experimental use exception. ${ }^{35} \mathrm{In}$ this case, the WTO Panel noted that experimental use defenses are based on the public interest notion that 'a key public policy purpose underlying patent laws is to facilitate the dissemination and advancement of technical knowledge' and that both society and scientists have a 'legitimate interest' in using patent disclosure to support the advancement of science and technology.

Pursuant to this, the TRIPS Agreement confers much flexibility on member countries to provide limited exceptions as long as they do not offend the restrictions set under Article 30 of the TRIPS Agreement. The authority of Article 30 was put to test when it was determined by the WTO Panel in WTO Canada - Pharmaceutical Products ${ }^{36}$ which concerned regulatory approval and stockpiling exceptions. In that case, whilst regulatory approval was upheld by the WTO Panel as a justifiable exception, stockpiling was not. It has been said that whilst countries are free to craft their own exceptions, they must comply with the three fundamental requirements set out in Article 30 of the TRIPS Agreement, i.e. the exception must be limited; it must not unreasonably conflict with the normal exploitation of the patent; and it must not unreasonably prejudice the legitimate interests of the patent owner, taking account of the legitimate interests of third parties.

It is not clear if the same experimental use provision engineered in Canada-Patent Protection 2000, Australian Law Reform Committee 2004, Gower Review of Intellectual Property 2006, would be similarly observed by ASEAN countries, and the same cannot be ascertained for

\footnotetext{
$35 \quad$ Canada: Patent Protection of Pharmaceutical Products: Complaint by the European Communities and their Member States, 17 March 2000, WT/DS114/R. (2000) WT/DS114/R.
} 
the Asia-Pacific region. However, based on judicial and industrial observations in both ASEAN and Asia-Pacific regions, there is a slow tectonic shift towards adopting this revised position based on national and climate change focuses.

\section{EXPERIMENTAL USE AND COMMERCIAL ENDS}

Experimental use exception can be found under section 37(1) of the Malaysian Patents Act 1983 which allows activities for the purpose of scientific research but not for acts done for industrial or commercial purposes. Section 37 is based to a substantial extent on the WIPO Model Law of 1979. These limitations of rights act as exceptions to liability. It is also known as "defenses," "permitted acts," "free uses" or "restrictions."

A major uncertainty with the current provision is whether it extends to scientific research with commercial ends. The Australian Law Reform Committee (2004) reported that the distinction between pure research and commercial research is no longer relevant in today's world. ${ }^{37}$ Even research institutes and educational institutions are nowadays expected to commercialise their research findings. Collaboration between universities and businesses with commercialisation objectives has increased significantly over the past decades since the discovery of the depletion of the ozone layer. Universities are expected to transfer their green technologies to the local industries which in turn are expected to spurn the national economy towards scientific innovation with climate change objectives. As observed by the Australian Law Reform Committee, the distinction between commercial and non-commercial is practically unrealistic. This is because,

'An important purpose of the patent system is to promote experimentation as a stepping stone to the development and commercialization of new or improved inventions. Whether experimentation is concluded by a non-profit or commercial entity, or

$37 \quad$ Genes and Ingenuity: Gene Patenting and Human Health (ALRC 99, 2004) available at www.alrc.gov.au/publications/report-99. 
with altruistic or commercial motivations, does not seem important to this purpose.'

The relevant provision in the UK is section 60(5) of the Patents Act 1977 which allows an act done privately without commercial purposes and an act done for experimental purposes relating to the subject matter of the invention. The experimental use provision is mirrored in the European Community Patent Convention (CPC) which stipulates that the exception only applies to experiments conducted privately for noncommercial purposes or related to the subject matter of the patented invention. These exception clauses have been interpreted as independent from one another. In other words, the requirements set out in section 60(5) (a) which states that an act must be 'private' or for 'noncommercial purposes' do not apply to section 60(5) (b) that permits those acts that go to the subject matter of the invention..$^{38}$ Based on section $60(5)$ (a) and (b), in order to fall within the exception to infringement for experimental use, such use must be directed to the invention claimed in the patent in question; regardless whether such experimental use is conducted with commercial objectives in mind or otherwise.

In the case where an infringing product is sold for experimental use by another, the vendor is liable for infringement (Hoffmann-La Roche \& Co A.G. v Harris Pharmaceuticals Ltd). ${ }^{39}$ The same result has been found in the context of seeking to exploit and sell technology (Inhale Therapeutics $v$ Quadrant). ${ }^{40}$ Similarly, to purchase and use infringing articles for the purpose of instructing pupils and to enable them to pull them to pieces and put them together again is not mere experimental use, and amounts to an infringement (United Telephone Co. $v$ Sharples). ${ }^{41}$

In sum, the Malaysian Patents Act 1983 allows 'scientific purposes,' but as soon as the research borders on commercial interest, the exception ends. Clearly, this does not support the National Green

\footnotetext{
38 The Research Or Experimental Use Exception: A Comparative Analysis, available at: <http://www.cipp.mcgill.ca/data/newsletters/ 00000050.pdf>

$39 \quad$ [1977] F.S.R. 200.

40 [2002] R.P.C. 21, at p. 419.

$41 \quad$ (1885) 2 R.P.C. 28.
} 
Technology Policy 2009 that aims to leverage on ETSs for two purposes; as an economic tool as well as environmental conservation.

\section{EXPERIMENTAL USE AND INVENTING AROUND A PATENT}

Another uncertainty in Malaysia is whether the act of inventing around an invention is caught under the experimental use exception under section 37(1) of the Patents Act 1983. The corresponding Australian provision, section 119C of the Patents Act 1990 contains a much broader experimental use exception which covers determining the properties of the invention; the scope of a claim relating to the invention; improving or modifying the invention; determining the validity of the patent or of a claim relating to the invention; and determining whether the patent for the invention would be, or has been, infringed by the doing of an act. Further, section 119C requires that the experimental activities be 'related to' the subject matter of the invention. This achieves two outcomes, i.e., first, that the exemption applies to experiments that include the claimed invention, so that the person undertaking the relevant work is not required to conduct patent searches before starting an experiment. Secondly, the exemption applies to experimentation on a patented invention, i.e. it does not cover experimentation using a patented invention. The exemption applies irrespective of whether the person undertaking the relevant act had in mind to later commercialise, for example, an improvement arising from the act, or whether that person was aware of the patent at the time the relevant act was undertaken. ${ }^{42}$ The exemption is very broad in the sense that it applies to all research activities where the predominant purpose of those activities are to gain new knowledge; to test a supposition or principle about the invention; or to improve on or modify the invention. Interestingly, an act that improves or modifies an invention is exempted relation to patents granted before, on or after this time An easy guide to Australia's new patent law under the Intellectual Property Laws Amendment (Raising the Bar) Act 2012, Freehills, available at: < http:/ /www.patents4life.com/wp-content/uploads/2012/04/Guide-toAustralias-new-patent-law.pdf >. 
from infringement, even if the improvement or modification is proposed for later commercialisation.

Besides the Australian provision, it is also useful to Malaysia to have provision allowing inventing around patented inventions and making improvements thereto like section 47 of the Indian Patents Act 1970.The Indian exception suggests that the exception be wide enough to even support activities such as "inventing around" the patented invention or the making of improvements thereto. ${ }^{43}$ This is buttressed by the fact that the Indian legislature consciously avoided limiting the scope of the exception to "non commercial" purposes. However, the key limitation is that the alleged use has to qualify as an "experiment" and cannot be a mere consumer type "use" where the patented product is merely enjoyed as it is without any investigation of underlying technology. ${ }^{44}$

If we were to follow strict common law, if an act is done for experimental purposes relating to the subject-matter of the action, it will not be an infringement. ${ }^{45}$ This was the purport of the Court of Appeal decision in Monsanto Co v Stauffer Chemical Co, ${ }^{46}$ where Dillon L.J. held that the word "experiment" was to be given its ordinary meaning and that the decisions under the old law as to what constituted "experimental purposes" were of no assistance. This approach was followed in a number of subsequent cases such as the Klinische Versuche $I I^{47}$ where the German Federal Supreme Court took a similar view. Further, Aldous J. in Smith Kline \& French Laboratories Ltd v Evans Medical Ltd., ${ }^{48}$ considered the words as having a limiting effect and held that for the protection to apply, the act must be done for purposes in relation to the subject matter of the invention in the claims of the patent alleged to be infringed, in respect of having a real and direct connection with that subject matter.

$43 \quad$ For a discussion on Indian position on experimental use, see Shamnad Basheer \& Prashant Reddy, "The Experimental Use” Exception Through a Developmental Lens," intell. prop. l. rev. 50 (2010) 831, 832.

$44 \quad$ Ibid.

45 Terrell on the Law of Patents, 17 ${ }^{\text {th }}$ Edition, Sweet \& Maxwell, 2010.

$46 \quad[1985]$ RPC 515.

47 Case XZR 68/94.

$48 \quad$ [1989]FSR 513. 
In sum, trials carried out to discover something unknown or to test a hypothesis or to find out whether something which is known to work in specific conditions will work in other conditions can be regarded as experiments. Trials carried out to demonstrate to a third party that a product works or in order to amass information to satisfy a third party such as a customer or regulatory authority that the product works as its maker claims are however not acts done for experimental purposes (Monsanto)..$^{49}$

In Malaysia, a strict interpretation of section 37 of the Patents Act 1983 entails that activities "inventing around" a patented invention or the making of improvements thereto are understood to be prohibited, a position not shared by India under the Indian Patents Act which permits 'inventing around' as well as Australian provision, It is thus clear that the provision in Australia and India which support the 'inventing around' patent and making improvements thereto are essential in the adaptation process of ESTs in light of climate change understandings and agreements hammered out under the auspices of COP Conferences, and most recently COP-18 in Doha, Qatar. ${ }^{50}$

Hence a liberal 'scientific purposes' should be adopted by Malaysia (and other restricting jurisdictions in Asia-Pacific) by allowing experimental use and inventing around a patent, so as to achieve a practical balance, as highlighted by the Prime Minister of Malaysia, Datuk Seri Najib Tun Razak, at the recent High Impact Biodiversity and Development Post 2015 Forum, KL, Malaysia 2013 when he advocate for "A balance between conservation and development" 51 in the New Economic Model (NEM) and Economic Transformation Programmes (ETP) respectively. In tandem with this call, there is a need to revise, amend and update the old position stolidly observed in section 37(1) of the Malaysian Patents Act 1983 which is a spanner in the works of promotion of green technologies for climate change utilisation at national research institutes, and at both public and private sectors.

\footnotetext{
[9 [1985] RPC 515.

50 "Doha Climate Change Conference - November 2012," at http:// unfccc.int/meetings/doha_nov_2012/meeting/6815.php.

51 High Impact Biodiversity and Development Post 2015 Forum, KL, Malaysia 2013 at http://www.nst.com.my/nation/general/a-balancebetween-conservation-and-development-says-najib-1.391781.
} 


\section{CONCLUSION}

Patent still forms an instrumental tool to support not only the development but also the diffusion of ESTs.$^{52}$ Having a balanced patent system is thus the way forward in these uncertain times caused by climate change. These technologies need to be diffused fast and this requires local adaptation and modification. In turn, a flexible scientific research and experimental exception, besides other patent reforms, is crucial to the process. The current distinction between research for the promotion of science and for altruistic or commercial purposes is not longer in line with modern reality. Furthermore, the Copyright Act 1987 has also been recently revised to remove the non commercial nature of research to qualify it as an exception.

Another concern is the possibility of inventing around a patented technology. A strict interpretation of patent that impedes inventing around without getting the consent of the patent owner is not only cost prohibitive but not suitable for speedy measures to alleviate the harshness of climate change impact.

If these two concerns are addressed, Malaysia should be able to spearhead its green technology initiatives in a more concerted manner towards climate change objectives. One strong recommendation is to reform obsolete scientific research provisions to be expanded to encompass all categories of green research and development relevant for the diffusion of green technology, regardless of its commercial and transformative ends. Failing this, the patent system will only serve to be a recipe for disaster; as a major obstacle to the effective research and development and diffusion of ESTs, in particular, for developing countries, and long-term interests of developed countries.

$52 \quad$ Derzko, Natalie M, "Using Intellectual Property and Regulatory Processes to Foster the Innovation and Diffusion of Environmental technologies," Harvard Environmental Law Review, 20 (1996) 3-60. 